\title{
Microwave-Assisted Synthesis of Hydroxybenzylidene-Andrographolides and Its Inhibitory Activity against HIV-1 Protease
}

\author{
Sandra Megantara ${ }^{1,2}$, Halimah Halimah², Annisa Putrianty², Daryono Hadi Tjahjono', Rahmana Emran Kartasasmita', \\ Maria Immaculata Iwo', Jutti Levita ${ }^{2^{*}}$, Slamet Ibrahim ${ }^{1}$ \\ 'School of Pharmacy, Bandung Institute of Technology, Jl. Ganesha 10 Bandung, West Java, 40132, Indonesia. \\ ${ }^{2}$ Faculty of Pharmacy, Universitas Padjadjaran, Jl. Raya Bandung-Sumedang Km 21, Jatinangor, West Java, 45363, Indonesia.
}

\begin{tabular}{l}
\hline ARTICLE INFO \\
\hline Article history: \\
Received on: $21 / 11 / 2017$ \\
Accepted on: $08 / 01 / 2018$ \\
Available online: $30 / 03 / 2018$
\end{tabular}

Key words:

Andrographolide; ARVs, HIV, HIV-1 protease inhibitors, hydroxybenzylidene andrographolide

\begin{abstract}
Andrographolide, a lacton diterpenoid, due to its many biological activities, was subjected to a semi-synthetic work by reacting andrographolide (a) with hydroxybenzaldehyde under microwave irradiation. This reaction led to three new andrographolide analogues, which are 3,19-2-hydroxybenzylidene andrographolide (b), 3,19-3-hydroxybenzylidene andrographolide (c), and 3,19-4-hydroxybenzylidene andrographolide (d), respectively. The yields were $85 \%, 86 \%$, $86 \%$ for compounds $\mathbf{b}, \mathbf{c}, \mathbf{d}$ respectively. These new compounds had already been studied previously by pharmacophore screening and molecular docking simulation, which revealed their affinity to HIV-1 protease. Furthermore, their inhibitory activity against HIV-1 protease was measured by in vitro fluorometric method at $(\mathrm{Ex} / \mathrm{Em})=330 / 450 \mathrm{~nm}$ which resulted $18.14,10.72,9.93,8.32 \mu \mathrm{M}$ respectively for $\mathrm{IC}_{50}$ value. The increased activity of these compounds may reflect the binding of the hydroxybenzaldehyde moiety with the hydrophobic area of the HIV-1 protease.
\end{abstract}

\section{INTRODUCTION}

HIV-1 protease inhibitors (PIs) have played a critical role in the success of highly active antiretroviral therapy for treatment of HIV-1 infected patients (Anderson et al., 2009; Shen et al., 2008; Thompson et al., 2012). PIs have the highest intrinsic antiviral activity (Jilek et al., 2012) and the only antiretroviral drugs that have been successfully used in monotherapy (Perez-Valero and Arribas, 2011). PIs are known to act by preventing cleavage of viral polyproteins into functional subunits, thereby inhibiting maturation of the virus (Swanstrom and Wills, 1997). A recent study has suggested that in mediating their antiviral effects, PIs affect multiple distinct steps in the life-cycle of the virus including both entry and post-entry events explaining their remarkable potency in suppressing viral replication (Rabi et al., 2013).

\section{"Corresponding Author}

Jutti Levita, Faculty of Pharmacy Universitas Padjadjaran, Jl. Raya Bandung-Sumedang km.21 Jatinangor West Java, 45363, Indonesia. E-mail:jutti.levita@unpad.ac.id
Our previous in silico studies indicated that andrographolide $\left(\mathrm{C}_{20} \mathrm{H}_{30} \mathrm{O}_{5}\right)$, an $\alpha$-alkylidene $\gamma$-butyrolactone, two olefin bonds at C-8 and C-12 and three hydroxyls at C-3, C-19 and C-14 (Nanduri et al., 2004), which has been analyzed by $\mathrm{X}$-ray crystallographic method and defined as 3-[2-[decahydro6-hydroxy-5-(hydroxymethyl)-5,8a-dimethyl-2-methylene-1naphthalenyl] ethylidine]dihydro-4-hydroxy-2 $(3 \mathrm{H})$-furanone (Smith et al., 1982), interacts with two important aspartate residues (Asp25 and Asp29) in the binding pocket of HIV-1 protease, similarly as its hydroxybenzylidene derivatives. Therefore, andrographolide and its derivatives potential to be developed as PIs for anti-HIV drugs (Megantara et al., 2017).

In order to determine the importance of the hydroxyl groups located at C-14 and C-19 combined with the presence of oxygen atom in the lactone ring of andrographolide for aspartic protease inhibitors activity, we modified this particular ligand by protecting its pharmacophores and adding hydroxyl-benzaldehyde moiety to fill in the hydrophobic empty space on the receptor's active site. Therefore, herein we report the semi-synthesis of andrographolide analogues by modifying a synthesis method 
that has been successfully carried out by Hadi Poerwono et al. (Poerwono et al., 2007) and furthermore an in vitro study to determine inhibitory activity against HIV-1 protease enzyme. Microwave-assisted organic synthesis was chosen to obtain a variety of advantages, including shorter reaction time, better yield together with simplicity in processing and handling (Razzaq and Kappe, 2008), and reduce hazardous intermediate products. This method complies on green chemistry, which is also called sustainable chemistry. The term green chemistry is defined as "the invention, design and application of chemical products and processes to reduce or to eliminate the use and generation of hazardous substances by keeping carbon footprint as low as possible. Microwave assisted organic synthesis has emerged as a new "lead" in organic synthesis and has provided the excellent momentum for many chemists to switch to microwave assisted chemistry (Gangrade et al., 2015).

\section{MATERIALS AND METHODS}

\section{Chemicals}

The chemicals were Andrographolide [Sigma-Aldrich], 2-Hydroxybenzaldehyde [Merck], 3-Hydroxybenzaldehyde [Sigma-Aldrich], 4-Hydroxybenzaldehyde [Merck], Pyridinium $p$-toluenesulfonate (PPTS) [Sigma-Aldrich], Triethylamine [SigmaAldrich], Sodium sulfate anhydrous [Sigma-Aldrich], Benzene [Merck], Dimethyl sulfoxide (DMSO) [Merck], Chloroform [Merck], Methanol [Merck], Ethyl acetate [Merck], n-Hexane [Merck], Lopinavir/Ritonavir $200 \mathrm{mg} / 50 \mathrm{mg}$ (Aluvia ${ }^{\circledR}$ ) as drug standard, and HIV-1 protease inhibitor screening kit [Bio Vision, USA].

\section{Instruments}

The synthesis reactions were carried out in an ace pressure tube using a Microwave synthesis reactor [Sineo MASII]. Melting point was determined on a Fisher-Johns apparatus (Fisher Scientific, Waltham, MA, USA) (uncorr). TLC Analysis was carried out using GF254 (Merck Millipore, Darmstadt, Germany) under UV Lamp 254/366 nm (CamagTM, Camag Chemie-Erzeugnisse \& Adsorptionstechnik AG, Muttenz, Switzerland). FTIR spectra were recorded in $\mathrm{KBr}$ powder on a Shimadzu ${ }^{\circledR}$ FT-IR Prestige-21 spectrophotometer (Shimadzu Corporation, Kyoto, Japan). Mass spectral data were recorded on MS Mariner BiospectrometryTM (Applied Biosystems, Foster
City, CA, USA). ${ }^{1} \mathrm{H}$ and ${ }^{13} \mathrm{C}-\mathrm{NMR}$ spectral data were recorded on an Agilent ${ }^{\circledR}$ (Agilent Technology, Santa Clara, CA, USA) at 500 $\mathrm{MHz}$ and $125 \mathrm{MHz}$, respectively. Instruments used for in vitro assay were fluorometer microplate readers (Varioskan FlashThermo Fisher scientific), black 96-well microtiter plate (Thermo Fisher scientific), plate shaker-thermostat (Biosan), vortex mixer (Julabo Paramix 3), and sonicator (FALC).

\section{Synthesis of hydroxybenzylidene-andrographolide derivatives}

Andrographolide $(0.1 \mathrm{~g}, 0.28 \mathrm{mmol})$ was reacted with either 2-hydroxybenzaldehyde $(0.3 \mathrm{~g}, 2.83 \mathrm{mmol})$ or 3-hydroxybenzaldehyde ( $0.3 \mathrm{~g}, 2.83 \mathrm{mmol})$ or 4-hydroxybenzaldehyde $(0.3 \mathrm{~g}, 2.83 \mathrm{mmol})$ in an ace-pressure tube using a Microwave synthesis reactor [Sineo MAS-II] (300W). Each of the mixture was then added by stirring with pyridinium $p$-toluenesulfonate $(20 \mathrm{mg}$ ) in benzene-dimethyl sulfoxide (4.5:0.5) for $3 \mathrm{~h}$. After the reaction was completed (checked by thin layer chromatography), the contents were treated with excess of triethylamine to quench the remaining catalyst. The reaction mixture was diluted with benzene and washed with water $(3$ times, $3 \times 10 \mathrm{~mL})$. The organic layer was separated, dried over sodium sulfate anhydrous, and concentrated by vacuum distillation. The product was purified by column chromatography using chloroform-methanol (20:1) as eluent.

\section{Inhibitory activity in vitro study against HIV-1 protease enzyme}

The solutions (substrate, standard, enzyme control, inhibitor control, andrographolide and its hydroxybenzylidene derivatives) were prepared according to the manual instruction of HIV-1 protease inhibitor screening kit (Bio Vision, USA). Aluvia ${ }^{\circledR}$ solution was prepared by dissolving the powder of Aluvia ${ }^{\circledR}$ tablet in methanol, by considering both ritonavir and lopinavir are freely soluble in that particular solvent (PDR, 2001; WHO, 2009). The fluorescence of each solution (substrate, standard, enzyme control, inhibitor control, andrographolide and its hydroxybenzylidene derivatives) was measured at $330 / 450 \mathrm{~nm}$ in a kinetic mode for 1-3 hour at $37^{\circ} \mathrm{C}$. Each measurement was replicated three times.

\section{RESULTS AND DISCUSSION}

In this work, we have successfully synthesized three new hydroxybenzylidene-andrographolide analogues under microwave irradiation as shown in Figure 1.

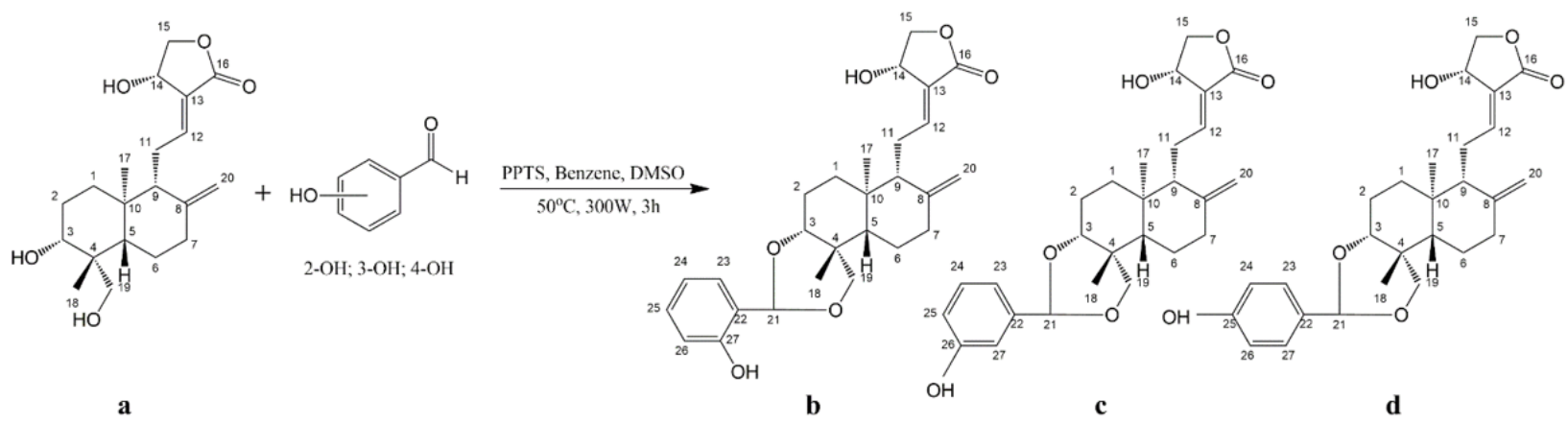

Fig. 1: The synthesis of 3,19-2-hydroxybenzylidene andrographolide (b), 3,19-3-hydroxybenzylidene andrographolide (c), and 3,19-4-hydroxybenzylidene andrographolide (d). 
Compound $\mathbf{b}$ was obtained as a white solid. Yield: $85 \%$, m.p.: $140-142^{\circ} \mathrm{C} .{ }^{1} \mathrm{H}-\mathrm{NMR}(500 \mathrm{MHz}, \mathrm{MeOH}-d 4): \delta$ (ppm) 0.75 (s, 3H, CH3), 1.22 (s, 3H, CH3), $1.30(\mathrm{t}, 2 \mathrm{H}, \mathrm{CH} 2, J=13 \mathrm{~Hz})$, $1,39(\mathrm{dt}, 2 \mathrm{H}, \mathrm{CH} 2, J=8.7 \mathrm{~Hz}, J=4.1 \mathrm{~Hz}), 1.80(\mathrm{dt}, 2 \mathrm{H}, \mathrm{CH} 2, J$ $=6.1 \mathrm{~Hz}, J=3.5 \mathrm{~Hz}), 1.90(\mathrm{t}, 1 \mathrm{H}, \mathrm{CH}, J=7.7 \mathrm{~Hz}), 2.03(\mathrm{dd}, 2 \mathrm{H}$, $\mathrm{CH} 2, J=12.8 \mathrm{~Hz}, J=6.0 \mathrm{~Hz}), 2.59(\mathrm{t}, 2 \mathrm{H}, \mathrm{CH} 2, J=6.6 \mathrm{~Hz}), 2.62$ $(\mathrm{t}, 1 \mathrm{H}, \mathrm{CH}, J=3.7 \mathrm{~Hz}), 4.15(\mathrm{dt}, 2 \mathrm{H}, \mathrm{CH} 2, J=8.2 \mathrm{~Hz}, J=2.0 \mathrm{~Hz})$, $4.47(\mathrm{dd}, 1 \mathrm{H}, \mathrm{CH}, J=6.1 \mathrm{~Hz}, J=4.1 \mathrm{~Hz}), 4.67$ (s, 2H, CH2), 4.89 (s, 2H, CH2), 5.98 (s, 1H, CH), 6.8 (d, 1H, Ar-H, J=7.5 Hz), 6.85

Pepstatin

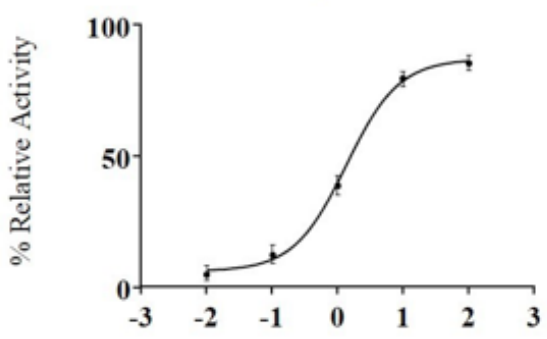

Log Doses (uM)

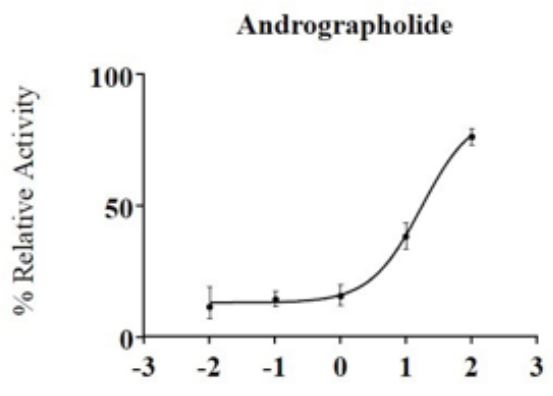

Log Doses (uM)

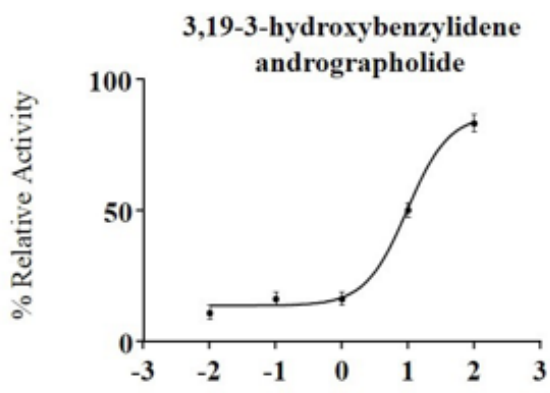

Log Doses (uM) (t, 1H, Ar-H, $J=7.5 \mathrm{~Hz}), 7.25$ (t, 1H, Ar-H, $J=7.5 \mathrm{~Hz}), 7.41(\mathrm{~d}$, $1 \mathrm{H}, \mathrm{Ar}-\mathrm{H}, J=7.5 \mathrm{~Hz}), 8.95$ (s, $1 \mathrm{H}, \mathrm{Ar}-\mathrm{OH}) .{ }^{13} \mathrm{C}-\mathrm{NMR}(125 \mathrm{MHz}$, MeOH- $d 4$ ): $\delta$ (ppm) 15.5, 23.4, 25.2, 25.7, 29.0, 38.1, 39.0, 40.0, 43.7, 56.3, 57.4, 65.0, 66.7, 76.2, 80.9, 102.1, 209.2, 115.0, 120.0, $126.8,129.8,137.4,148.8,149.4,154.7,172.6$. MS (EI): [M] $+m / z$ $=454.24(33), 436.26(100), 420.25(21), 284.19(4), 256.19(15)$. FT-IR 3396, 70 (alcohol O-H); 2927,03 (C-C-H); 1726,32 (Ester $\mathrm{C}=\mathrm{O}$ ); 1674,24 (Aldehyde and ketone $\mathrm{C}=\mathrm{O}$ ); 1647,24 (Aromatic $\mathrm{C}=\mathrm{C}) ; 1296,19\left(\mathrm{Sp}^{2} \mathrm{C}-\mathrm{O}\right)$.
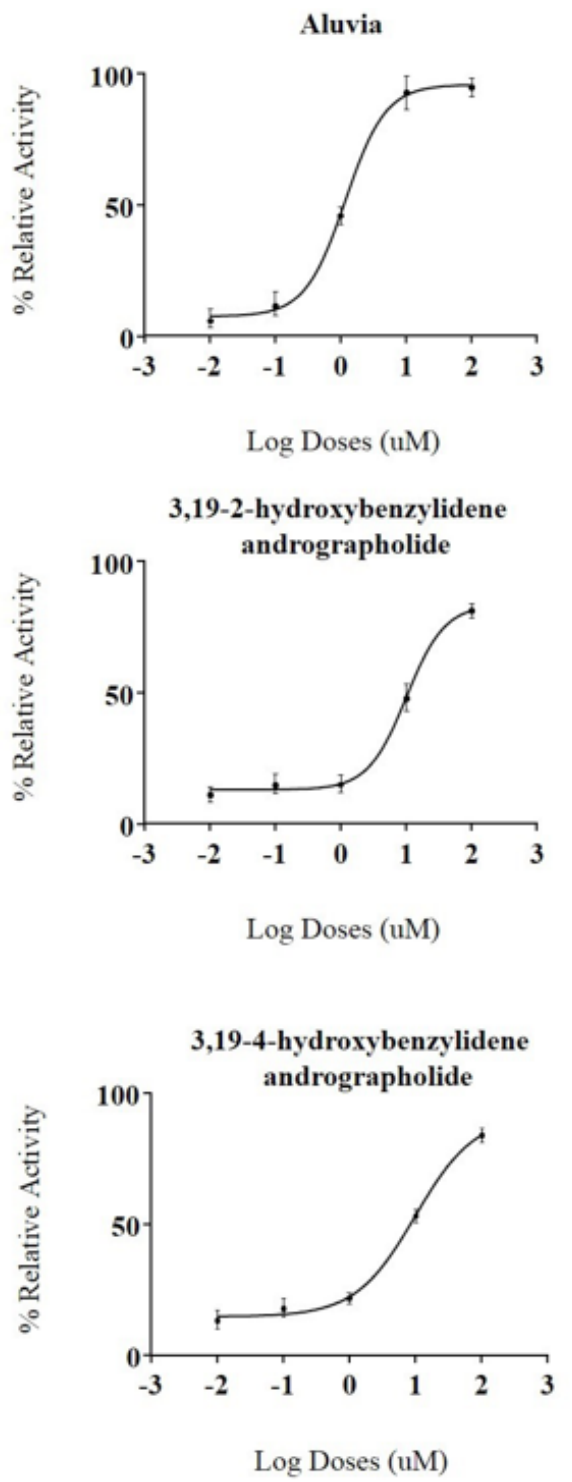

Fig. 2: Relative inhibition curve of the compounds against HIV-1 protease.

Compound c was obtained as a white solid. Yield: $86 \%$, m.p.: $167-170^{\circ} \mathrm{C} .{ }^{1} \mathrm{H}-\mathrm{NMR}(500 \mathrm{MHz}, \mathrm{MeOH}-d 4): \delta$ (ppm) 0.73 (s, 3H, CH3), 1.20 (s, 3H, CH3), 1.29 (t, 2H, CH2, J=13 Hz), $1,35(\mathrm{dt}, 2 \mathrm{H}, \mathrm{CH} 2, J=8.7 \mathrm{~Hz}, J=4.1 \mathrm{~Hz}), 1.77(\mathrm{dt}, 2 \mathrm{H}, \mathrm{CH} 2, J$ $=6.1 \mathrm{~Hz}, J=3.5 \mathrm{~Hz}), 1.88(\mathrm{t}, 1 \mathrm{H}, \mathrm{CH}, J=7.7 \mathrm{~Hz}), 2.02(\mathrm{dd}, 2 \mathrm{H}$, $\mathrm{CH} 2, J=12.8 \mathrm{~Hz}, J=6.0 \mathrm{~Hz}), 2.55(\mathrm{t}, 2 \mathrm{H}, \mathrm{CH} 2, J=6.6 \mathrm{~Hz}), 2.60$ (t, $1 \mathrm{H}, \mathrm{CH}, J=3.7 \mathrm{~Hz}), 4.11(\mathrm{dt}, 2 \mathrm{H}, \mathrm{CH} 2, J=8.2 \mathrm{~Hz}, J=2.0 \mathrm{~Hz})$, $4.42(\mathrm{dd}, 1 \mathrm{H}, \mathrm{CH}, J=6.1 \mathrm{~Hz}, J=4.1 \mathrm{~Hz}), 4.63(\mathrm{~s}, 2 \mathrm{H}, \mathrm{CH} 2), 4.85$ (s, 2H, CH2), 5.95 (s, 1H, CH), 6.7 (d, 1H, Ar-H, J=7.5 Hz), 6.85 (t, 1H, Ar-H, $J=7.5 \mathrm{~Hz}), 7.25$ (d, 1H, Ar-H, $J=7.5 \mathrm{~Hz}), 7.5$ (s, $1 \mathrm{H}, \mathrm{Ar}-\mathrm{H}), 8.8$ (s, $1 \mathrm{H}, \mathrm{Ar}-\mathrm{OH}) .{ }^{13} \mathrm{C}-\mathrm{NMR}(125 \mathrm{MHz}, \mathrm{MeOH}-d 4)$ : $\delta$ (ppm) 15.2, 23.0, 24.9, 25.5, 28.9, 37.8, 38.7, 39.5, 40.6, 56.0, 57.1, 64.6, 66.2, 76.1, 79.9, 101.7, 208.5, 114.2, 118.6, 126.5, $129.4,137.2,147.1,148.4,153.3,170.5 . \mathrm{MS}(\mathrm{EI}):[\mathrm{M}]+m / z=$ 454.20(35), 436.26(100), 420.24(20), 284.18(5), 256.15(17). FT-IR 3396,70 (alcohol O-H); 2927,99 (C-C-H); 1727,26 (Ester 
$\mathrm{C}=\mathrm{O}$ ); 1673,28 (Aldehyde and ketone $\mathrm{C}=\mathrm{O}$ ); 1580,69 (Aromatic $\mathrm{C}=\mathrm{C}) ; 1220,96\left(\mathrm{Sp}^{2} \mathrm{C}-\mathrm{O}\right)$.

Compound $\mathbf{d}$ was obtained as a white solid. Yield: $86 \%$, m.p.: $192-194^{\circ} \mathrm{C} .{ }^{1} \mathrm{H}-\mathrm{NMR}(500 \mathrm{MHz}, \mathrm{MeOH}-d 4): \delta$ (ppm) 0.70 (s, 3H, CH3), $1.21(\mathrm{~s}, 3 \mathrm{H}, \mathrm{CH} 3), 1.32(\mathrm{t}, 2 \mathrm{H}, \mathrm{CH} 2, J=13 \mathrm{~Hz})$, $1,31(\mathrm{dt}, 2 \mathrm{H}, \mathrm{CH} 2, J=8.7 \mathrm{~Hz}, J=4.1 \mathrm{~Hz}), 1.68(\mathrm{dt}, 2 \mathrm{H}, \mathrm{CH} 2, J$ $=6.1 \mathrm{~Hz}, J=3.5 \mathrm{~Hz}), 1.83(\mathrm{t}, 1 \mathrm{H}, \mathrm{CH}, J=7.7 \mathrm{~Hz}), 2.11(\mathrm{dd}, 2 \mathrm{H}$, $\mathrm{CH} 2, J=12.8 \mathrm{~Hz}, J=6.0 \mathrm{~Hz}), 2.51(\mathrm{t}, 2 \mathrm{H}, \mathrm{CH} 2, J=6.6 \mathrm{~Hz}), 2.48$ $(\mathrm{t}, 1 \mathrm{H}, \mathrm{CH}, J=3.7 \mathrm{~Hz}), 4.10(\mathrm{dt}, 2 \mathrm{H}, \mathrm{CH} 2, J=8.2 \mathrm{~Hz}, J=2.0 \mathrm{~Hz})$, $4.37(\mathrm{dd}, 1 \mathrm{H}, \mathrm{CH}, J=6.1 \mathrm{~Hz}, J=4.1 \mathrm{~Hz}), 4.56(\mathrm{~s}, 2 \mathrm{H}, \mathrm{CH} 2), 4.78$ (s, 2H, CH2), 5.92 (s, 1H, CH), 6.7 (d, 1H, Ar-H, J=7.5 Hz), 6.85 $(\mathrm{d}, 1 \mathrm{H}, \mathrm{Ar}-\mathrm{H}, J=7.5 \mathrm{~Hz}), 7.25(\mathrm{~d}, 1 \mathrm{H}, \mathrm{Ar}-\mathrm{H}, J=7.5 \mathrm{~Hz}), 7.35$ (d, $1 \mathrm{H}, \mathrm{Ar}-\mathrm{H}, J=7.5 \mathrm{~Hz}), 8.62$ (s, Ar-OH). ${ }^{13} \mathrm{C}-\mathrm{NMR}(125 \mathrm{MHz}$, MeOH-d4): $\delta$ (ppm) 15.0, 22.2, 24.2, 25.5, 28.2, 38.0, 37.7, 38.1, $42.7,55.5,56.1,62.9,65.4,74.8,80.2,101.2,208.1,114.0,118.2$, $124.5,128.9,136.2,146.1,147.4,152.5,170.2 . \mathrm{MS}(\mathrm{EI}):[\mathrm{M}]+m / z$ = 454.20(36), 436.26(100), 420.27(22), 284.20(6), 256.21(19). FT-IR 3217,32 (alcohol O-H); 2927,99 (C-C-H); 1726,32 (Ester $\mathrm{C}=\mathrm{O}$ ); 1674,24 (Aldehyde and ketone $\mathrm{C}=\mathrm{O}$ ); 1598,05 (Aromatic $\mathrm{C}=\mathrm{C}) ; 1218,07\left(\mathrm{Sp}^{2} \mathrm{C}-\mathrm{O}\right)$.

Inhibitory activity against HIV-1 protease was performed by measuring the amount of product formed in the reaction catalyzed by the HIV-1 protease expressed by $\mathrm{IC}_{50}$ value which was calculated from relative inhibition curve (Figure 2).

Most current HIV PIs were designed to mimic the substrate transition state. The hydroxyl group, particularly - $\mathrm{CH}-\mathrm{COH}-\mathrm{CH} 2$ - of the inhibitor, interacts with the carboxyl group of the protease active site residues, Asp 25 and Asp 25', by hydrogen bonds. The inhibitor-contacting residues of HIV protease are relatively conserved, including Gly 27, Asp 29, Asp 30, and Gly 48 , but the accumulation of drug-resistance mutations alters the structure of HIV protease and causes treatment failure (Lv et al., 2015). Our previous in silico studies indicated that andrographolide interacted with two important aspartate residues (Asp25 and
Asp29) in the binding pocket of HIV-1 protease, similarly as its hydroxybenzylidene derivatives (Megantara et al., 2017). Inhibitory activity in-vitro against HIV-1 protease enzyme was used pepstatin as inhibitor standard due to its powerful inhibitory activity for proteases (Marciniszyn et al., 1976). Besides Pepstatin, we also used Aluvia ${ }^{\circledR}$ tablet, contains lopinavir and ritonavir as inhibitor standard. Lopinavir is a novel protease inhibitor (PI) developed from ritonavir. Coadministration with low-dose ritonavir had significantly improved the pharmacokinetic properties and furthermore increased the activity of lopinavir against HIV-1 protease. Coformulated lopinavir/ ritonavir should be regarded as a first-line option when including a PI in the management of HIV-1 infection (Cvetkovic and Goa, 2003). When lopinavir and ritonavir are given simultaneously, ritonavir will inhibit CYP3A4 isoenzyme in the liver that increases the concentration of lopinavir (Kumar et al., 1999). Furthermore, cell-to-cell spread of HIV-1 was potently blocked in the presence of both lopinavir and darunavir at doses corresponding to the maximum plasma concentrations $\left(\mathrm{C}_{\max }\right)(14 \mu \mathrm{M}$ LPV; $12 \mu \mathrm{M}$ DRV) achieved in vivo (Back et al., 2008; Lafeuillade et al., 2002).

Result showed that its $\mathrm{IC}_{50}$ was $1.61 \pm 0.21 \mu \mathrm{M}$, which was close to other report: $2.0 \mu \mathrm{M}$ (Sarubbi et al., 1993). Aluvia ${ }^{\circledR}$ tablet, contains lopinavir and ritonavir, was used as drug standard and its $\mathrm{IC}_{50}$ value was $1.12 \pm 0.11 \mu \mathrm{M}$. The inhibitory activity of Aluvia ${ }^{\circledR}$ against HIV protease is stronger than pepstatin. The $\mathrm{IC}_{50}$ of andrographolide, 3,19-2 hydroxybenzylidene andrographolide, 3,19-3 hydroxybenzylidene andrographolide, and 3,19-4 hydroxybenzylidene andrographolide were $18.14 \pm 5.95 \mu \mathrm{M}, 10.72$ $\pm 1.39 \mu \mathrm{M}, 9.93 \pm 1.24 \mu \mathrm{M}$, and $8.32 \pm 1.07 \mu \mathrm{M}$, respectively. It was noticeable that the $\mathrm{IC}_{50}$ of andrographolide and its derivatives was higher than the standards (Figure 3). All hydroxybenzylideneandrographolide analogues showed better inhibition than its parent compound, but derivate-3 (3,19-4 hydroxybenzylidene andrographolide) is the strongest in inhibiting the enzyme.

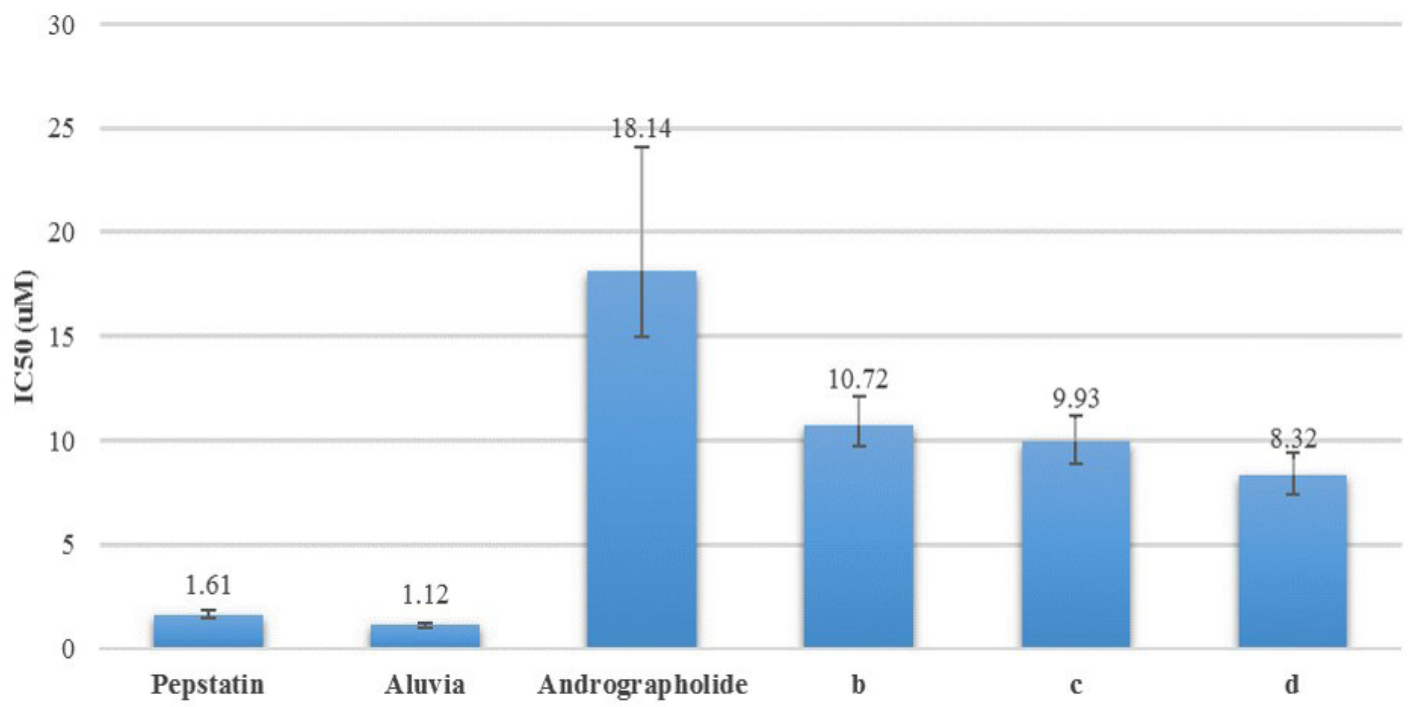

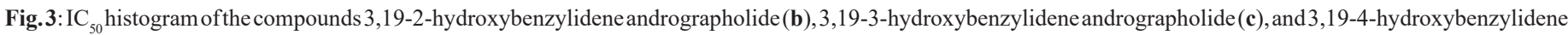
andrographolide (d). 


\section{CONCLUSION}

The microwave-assisted synthesis had resulted three new hydroxybenzylidene-andrographolides with sufficient yields (85-86\%). Andrographolide and its hydroxybenzylidene derivatives indicated inhibitory activity against HIV-1 protease, which proves that the replacement of hydroxyl groups at C-3 and C-19 with hydroxybenzaldehyde is responsible for increasing the activity. The increased activity of these compounds may reflect the binding of the hydroxybenzaldehyde moiety with the hydrophobic area of the HIV-1 protease. The strongest activity was showed by 3,19-4 hydroxybenzylidene andrographolide.

\section{ACKNOWLEDGEMENT}

This project was supported by Research and Innovation Scientific Group Grant of the Bandung Institute of Technology 2016.

\section{REFERENCES}

Anderson J, Schiffer C, Lee SK, Swanstrom R. Viral protease inhibitors. Handb Exp Pharmacol, 2009; (189): 85-110.

Back D, Sekar V, Hoetelmans RM. Darunavir: pharmacokinetics and drug interactions. Antivir Ther, 2008; 13(1): 1-13.

Cvetkovic RS, Goa KL. Lopinavir/ritonavir: a review of its use in the management of HIV infection. Drugs, 2003; 63(8): 769-802.

Fujita T, Fujitani R, Takeda Y, Takaishi Y, Yamada T, Kido M, Miura I. On the diterpenoids of Andrographis paniculata: X-ray crystallographic analysis of andrographolide and structure determination of new minor diterpenoids. Chem. Pham. Bull, 1984; 32: 2117-2125.

Gangrade D, Lad SD, Mehta AL. Overview on microwave synthesis - Important tool for green Chemistry. Int J Res Pharm Sci, 2015; 5(2): $37-42$

Jilek BL, Zarr M, Sampah ME, Rabi SA, Bullen CK, Lai J, Shen L, Siliciano RF. A quantitative basis for antiretroviral therapy for HIV-1 infection. Nat Med, 2012; 18(3): 446-451.

Kumar GN, Dykstra J, Roberts EM, Jayanti VK, Hickman D, Uchic J, Yao Y, Surber B, Thomas S, Granneman GR. Potent inhibition of the cytochrome P-450 3A-mediated human liver microsomal metabolism of a novel HIV protease inhibitor by ritonavir: A positive drug-drug interaction. Drug Metab Dispos, 1999; 27(8): 902-908.

Lafeuillade A, Solas C, Halfon P, Chadapaud S, Hittinger G, Lacarelle B. Differences in the detection of three HIV-1 protease inhibitors in non-blood compartments: clinical correlations. HIV Clin Trials, 2002; $3(1): 27-35$

Low M, Khoo CS, Munch G, Govindaraghavan S, Sucher NJ. An in vitro study of anti-inflammatory activity of standardised Andrographis paniculata extracts and pure andrographolide. BMC Complement Altern Med, 2015; 15: 18

Lv Z, Chu Y, Wang Y. HIV protease inhibitors: a review of molecular selectivity and toxicity. HIV AIDS (Auckl), 2015; 7: 95-104.

Marciniszyn J, Jr., Hartsuck JA, Tang J. Mode of inhibition of acid proteases by pepstatin. J Biol Chem, 1976; 251(22): 7088-7094.

Megantara S, Tjahjono DH, Kartasasmita RE, Iwo MI, Levita J, Ibrahim S. In Silico Study of Andrographolide and Its Derivatives as HIV-1 Protease Inhibitors for Anti-HIV/AIDS Drug Discovery. Res J Pharm, Biol Chem Sci, 2017; 8(1S): 222-228.

Mishra K, Dash AP, Dey N. Andrographolide: A Novel Antimalarial Diterpene Lactone Compound from Andrographis paniculata and Its Interaction with Curcumin and Artesunate. J Trop Med, 2011; 2011: 579518 .

Nanduri S, Nyavanandi VK, Thunuguntla SS, Kasu S, Pallerla MK, Ram PS, Rajagopal S, Kumar RA, Ramanujam R, Babu JM, Vyas K,
Devi AS, Reddy GO, Akella V. Synthesis and structure-activity relationships of andrographolide analogues as novel cytotoxic agents. Bioorg Med Chem Lett, 2004; 14(18): 4711-4717.

Nugroho AE, Andrie M, Warditiani NK, Siswanto E, Pramono S, Lukitaningsih E. Antidiabetic and antihiperlipidemic effect of Andrographis paniculata (Burm. f.) Nees and andrographolide in high-fructose-fat-fed rats. Indian J Pharmacol, 2012; 44(3): 377-381.

PDR. 2001. Physicians Desk Reference (55th ed.). Montvale. NJ: Medica Economics Co.

Perez-Valero I, Arribas JR. Protease inhibitor monotherapy. Curr Opin Infect Dis, 2011; 24(1): 7-11.

Poerwono H, Hattori Y, Kubo H, Higashiyama K. Structure Modification of Andrographolide to Improve Its Potency as Anticancer. Indo. J. Chem, 2007; 7(2): 202-207.

Rabi SA, Laird GM, Durand CM, Laskey S, Shan L, Bailey JR, Chioma S, Moore RD, Siliciano RF. Multi-step inhibition explains HIV-1 protease inhibitor pharmacodynamics and resistance. J Clin Invest, 2013; 123(9): 3848-3860.

Razzaq T, Kappe CO. On the energy efficiency of microwaveassisted organic reactions. ChemSusChem, 2008; 1(1-2): 123-132.

Sarubbi E, Seneci PF, Angelastro MR, Peet NP, Denaro M, Islam K. Peptide aldehydes as inhibitors of HIV protease. FEBS Lett, 1993; 319(3): 253-256.

Shen L, Peterson S, Sedaghat AR, McMahon MA, Callender M, Zhang H, Zhou Y, Pitt E, Anderson KS, Acosta EP, Siliciano RF. Doseresponse curve slope sets class-specific limits on inhibitory potential of anti-HIV drugs. Nat Med, 2008; 14(7): 762-766.

Smith AB, Toder BH, Carroll PJ, Donohue J. Andrographolide: an X-ray crystallographic analysis. Journal of Crystallographic and Spectroscopic Research, 1982; 12(4): 309-319.

Swanstrom R, Wills JW. (1997). Synthesis, Assembly, and Processing of Viral Proteins. In J. M. Coffin, S. H. Hughes \& H. E. Varmus (Eds.), Retroviruses. Cold Spring Harbor (NY).

Thompson MA, Aberg JA, Hoy JF, Telenti A, Benson C, Cahn P, Eron JJ, Gunthard HF, Hammer SM, Reiss P, Richman DD, Rizzardini G, Thomas DL, Jacobsen DM, Volberding PA. Antiretroviral treatment of adult HIV infection: 2012 recommendations of the International Antiviral Society-USA panel. JAMA, 2012; 308(4): 387-402.

Trivedi NP, Rawal UM, Patel BP. Hepatoprotective effect of andrographolide against hexachlorocyclohexane-induced oxidative injury. Integr Cancer Ther, 2007; 6(3): 271-280.

Vasu S, Palaniyappan V, Badami S. A novel microwaveassisted extraction for the isolation of andrographolide from Andrographis paniculata and its in vitro antioxidant activity. Nat Prod Res, 2010; 24(16): $1560-1567$.

Wen L, Xia N, Chen X, Li Y, Hong Y, Liu Y, Wang Z, Liu Y. Activity of antibacterial, antiviral, anti-inflammatory in compounds andrographolide salt. Eur J Pharmacol, 2014; 740: 421-427.

WHO. 2009. Lopinavir Draft Proposal for The International Pharmacopoeia for Comment. 1211 Geneva 27, Switzerland: World Health Organization.

Yuan H, Sun B, Gao F, Lan M. Synergistic anticancer effects of andrographolide and paclitaxel against A549 NSCLC cells. Pharm Biol, 2016: 1-7.

How to cite this article:

Megantara S, Halimah H, Putrianty A, Tjahjono DH, Kartasasmita RE, Iwo MI, Levita J, Ibrahim S. Microwaveassisted synthesis of hydroxybenzylidene-andrographolides and its inhibitory activity against HIV-1 protease. J App Pharm Sci, 2018; 8(03): 009-013. 